\title{
Human endometrial milk fat globule-epidermal growth factor 8 (MFGE8) is up regulated by estradiol at the transcriptional level, and its secretion via microvesicles is stimulated by human chorionic gonadotropin (hCG)
}

\author{
Abbaa Sarhan ${ }^{1,5}$, Silvina Bocca ${ }^{1,4^{*}}$, Liang Yu ${ }^{1}$, Sandra Anderson ${ }^{1}$, Terry Jacot ${ }^{1}$, Tanya Burch ${ }^{2}$, Julius O. Nyalwidhe ${ }^{2}$, Claretta Sullivan $^{3}$, \\ Mandeep Kaur ${ }^{6}$, Vladimir B. Bajic ${ }^{6}$ and Sergio Oehninger ${ }^{1}$ \\ *Correspondence: boccaS@evms.edu \\ 'The Jones institute for Reproductive Medicine, Department of Obstetrics and Gynecology, USA. \\ ${ }^{2}$ Department of Microbiology and Molecular Cell Biology -Center for Biomedical Proteomics, USA. \\ ${ }^{3}$ Department of Surgery, Eastern Virginia Medical School, Norfolk, Virginia 23507, USA. \\ ${ }^{4}$ The Jones institute for Reproductive Medicine, Eastern Virginia Medical School, Department of Obstetrics and Gynecology, USA. \\ ${ }^{5}$ Columbia Fertility Associates, 2440 M St NW, Suite 401, Washington DC 20037, USA. \\ ${ }^{6}$ Computational Bioscience Research Center, King Abdullah University of Science and Technology, Thuwal 23955-6900, Kingdom of \\ Saudi Arabia.
}

\begin{abstract}
Objective: We have recently showed that MFGE8, a novel epithelial cell protein in the human endometrium, upregulated during the window of implantation. We hypothesized that MFGE8 may act as a key modulator of endometrial remodeling and trophoblast invasion. The aims of this study were (i) to investigate the in vitro regulation of human endometrial epithelial cells $M F G E 8$ transcription, translation, and secretion by sex steroids and hCG; and (ii) to examine the possibility of $M F G E 8$ secretion via microvesicles.

Design: Experimental in vitro study using Ishikawa cells.

Setting: University center.

Interventions: Treatment with estradiol (E2), progesterone (P4), and human chorionic gonatropin (hCG).

Main outcome measures: MFGE8 mRNA and protein expression, and identification of secreted microvesicles by mass spectrometry (MS) and immunoblotting.

Results: $\mathrm{E}_{2}$, but not P4 or hCG, significantly upregulated MFGE8 mRNA expression. hCG significantly increased MFGE8 secretion. Microvesicels obtained after ultracentrifugation were visualized with atomic force microscopy ranging from $\sim 100 \mathrm{to} 200 \mathrm{~nm}$. In addition to the expected $46 \mathrm{kD}$ protein, the microvesicles contained a second form of secreted MFGE 8 measuring $\sim 30 \mathrm{kD}$ which was confirmed by MS.

Conclusions: We demonstrated (i) dual effects of $\mathrm{E}_{2}$ and hCG on the regulation of MFGE8, and (ii) MFGE8 protein secretion in association with microvesicles. MFGE8 has the potential to modulate endometrial function and implantation via exocrine and/ or paracrine-autocrine effects. To the best of our knowledge, this is the first demonstration of microvesicular secretion of any regulatory protein by endometrial epithelial cells, providing initial evidence suggestive of microvesicular participation in cellular trafficking information in the non-pregnant and pregnant endometrium.
\end{abstract}

Keywords: Endometrium, gene expression, $M F G E 8$, microvesicles

\section{Introduction}

The nature and roles of the key molecules involved in blastocyst implantation is still under investigation [1-5]. Decidualization is the progressive remodeling of the endometrium that provides a receptive environment referred to as the "window of implantation" [6-10]. The gene expression profiles of the receptive endometrium have been characterized [11-13]. Among them, our group showed that milk fat globule EGF factor 8 (MFGE8), an endometrial gene not previously linked to the endometrium or implantation, was transcriptionally up-regulated 2.6- fold during the receptive phase [14]. We postulated MFGE8 as a novel glycoprotein with key roles in the regulation of endometrial function [15].

The secreted glycoprotein, MFGE8 (also known as lactadherin, SED1, or breast antigen 46 [BA46]) was initially described as a component of the milk fat globule membrane, which is mainly secreted in microvesicles. It has also been suggested as a tumor marker in breast carcinomas [16,17]. Human MFGE8 is a $46 \mathrm{kD}$ glycoprotein peripherally associated with the cell membrane having two N-terminal EGF-like repeats, one of which includes 
Sarhan et al. Cell signalling and Trafficking 2013,

an Arginine-Glycine-Aspartic acid (RGD) motif that serves as the ligand to its $\mathbf{a v} \boldsymbol{\beta} \mathbf{3}$ integrin receptor, facilitating cell adhesion and signal transduction. The two C-terminal discoidin C1-C2 domains are homologous to coagulation factors $V$ and VIII, and are responsible for binding to cell membrane phospholipids or cell surface carbohydrate moieties as well as to the extracellular matrix $[18,19]$.

MFGE8 has a variety of functions in many extra-uterine tissues related to apoptosis, cell adhesion and remodeling, neovascularization, and immunomodulation. In the breast it promotes phagocytosis of apoptotic cells by $\boldsymbol{\alpha v} \boldsymbol{\beta} 3 / \boldsymbol{\beta} 5$ integrin-expressing phagocytes [20], as well as in endothelial and epithelial cells $[21,22]$. Prolactin is a potent inducer of MFGE8 expression in macrophages [23]. In systemic endothelial cells, MFGE8 binding to $\boldsymbol{\alpha v} \boldsymbol{\beta} \mathbf{\beta} / \boldsymbol{\beta} 5$ integrins promotes VEGFinduced survival and proliferation, leading to angiogenesis [24]. MFGE8 also stimulates cell/cell and cell/extracellular matrix adhesion during sperm-oocyte interaction $[\mathbf{1 8 , 2 5 ]}$. In intestinal, mammary gland, and epididymal epithelia, MFGE8 regulates migration of epithelial cells [18,26-28]. MFGE8 also protects against symptomatic rotavirus infection [29].

We recently demonstrated that MFGE8 protein is predominantly localized to the epithelial compartment of the human endometrium, both in luminal and glandular epithelial cells, and with intense staining at both apical and basal cellular compartments [15]. The MFGE8 receptor, integrin av $\beta 3$, was present in the epithelial and stromal compartments, with cycle-dependent and coincident peak expressions at midsecretory phase [15]. We also showed that MFGE8 protein was up regulated by prolactin in primary endometrial epithelial cell cultures. This finding supports a modulatory role for prolactin as a stromal-epithelial paracrine factor controlling MFGE8 production [15]. Furthermore, we reported that MFGE8 protein is highly expressed in human chorionic villi at all trimesters of gestation (in both cytotrophoblasts and syncytiotrophoblasts), and in murine implantation sites [30]. We also observed that MFGE8 has pro-apoptotic activity in human endometrial stromal cells suggesting paracrine modulation [31]. Finally, we presented new evidence that recombinant MFGE8 modulates endometrial endothelial cell proliferation and adhesion under in vitro conditions [32].

Here, the objective was to investigate the in vitro regulation of human MFGE8 transcription, production and secretion in endometrial epithelial cells by estradiol $\left(E_{2}\right)$, progesterone (P4), and human chorionic gonadotropin ( $\mathrm{hCG}$ ). To accomplish this goal, we used Ishikawa cells, an established in vitro cell culture model surrogate for human endometrial epithelium and known to display estrogen (ER) and progesterone (PR) receptors in culture [33-36]. Given that $E_{2}$ priming and $P 4$ are active participants in the luteal phase endometrial transformation, and that hCG is one of the earliest embryonic products in a pregnancy cycle [37], we hypothesized that these hormones may directly regulate endometrial MFGE8 production.

\section{Materials and methods}

\section{Ishikawa cells culture and treatment}

Ishikawa cells were cultured in DMEM/F12 containing 100 $\mathrm{U} / \mathrm{ml}$ penicillin and $100 \mu \mathrm{g} / \mathrm{ml}$ streptomycin (Gibco, Grand Island, NY) and supplemented with $5 \%$ fetal bovine serum (FBS, Atlanta Biological, Lawrenceville, GA) at $37^{\circ} \mathrm{C}$ in a $5 \%$ $\mathrm{CO}_{2}$ atmosphere. The cells were trypsinized and seeded in DMEM/F12 containing 5\% charcoal stripped FBS (Gibco) in either 6 or 12- well plates (for experiments measuring mRNA and intracellular protein) or $75 \mathrm{ml}$ flasks (for experiments measuring secreted protein), and upon reaching 50-80\% confluence used in experiments with hormone treatments as described below $[34,36,38]$.

For mRNA studies, the Ishikawa cells were then treated with $0.1 \%$ ethanol (as vehicle control), with $17 \beta-\mathrm{E}_{2}$ (Sigma Aldrich Co., St. Louis, MO) for 24 hours $\left(10^{-8} \mathrm{M}\right)$, with P4 $\left(10^{-6}\right.$ $M$, Sigma) for 24 hours, or with a sequential treatment of $E_{2}$ for 24 hours $\left(10^{-8} \mathrm{M}\right)$, then followed by P4 $\left(10^{-6} \mathrm{M}\right)$ for another 24 hours, ( $n=6$ experiments per treatment). The cells were collected and stored at $-80^{\circ} \mathrm{C}$ until later use for mRNA extraction. In further experiments, Ishikawa cells were treated with recombinant hCG at $500 \mathrm{mlU} / \mathrm{ml}$ (Sigma) for 24 and 72 hours $(n=6$ per time) $[31,39]$.

For intracellular protein studies, Ishikawa cells grown in the 12-well plates were treated with $17 \beta-E_{2} 10^{-7} \mathrm{M}$ or $\mathrm{P} 410^{-6} \mathrm{M}$, alone and also in combination, and additionally with recombinant hCG $500 \mathrm{mlU} / \mathrm{ml}$ alone (without steroids), in duplicates, for 24,48 , and 72 hours. Finally, for secreted protein studies, the $75 \mathrm{ml}$ flasks were treated with $17 \beta-\mathrm{E}_{2} 10^{-7} \mathrm{M}$ or $\mathrm{P} 410^{-6} \mathrm{M}$ (alone and also in combination), and additionally with $\mathrm{hCG}$ at $500 \mathrm{mlU} / \mathrm{ml}$ alone (without steroids) ( $\mathrm{n}=8$ experiments) in 8 $\mathrm{ml}$ of media for 72 hours. The $8 \mathrm{ml}$ of media was centrifuged at $1000 \mathrm{rpm}$ for 5 minutes to remove cellular debris before storage at $-80^{\circ} \mathrm{C}$.

Immunohistochemistry, immunofluorescence, and RNA extraction and real time RT-PCR

Antibodies and dilutions used for immunostaining, as well as primers and PCR quantification and analysis methods are presented in Supplemental Materials.

\section{In silico promoter analysis for EREs and PREs}

We analyzed the $5^{\prime}$-flanking regions of MFGE8 gene for the presence of putative estrogen and P4-response elements (EREs and PREs), as previously described by us $[14,36,40]$. For this in silico identification of EREs and PREs, we used two tools, DEREF (Dragon ERE Finder) [40] and Dragon PRE Locator (http://apps.sanbi.ac.za/PRE/index.php). We extracted promoter regions that correspond to $3000 \mathrm{bp}$ upstream and 200 bp downstream $(-3000,+200)$ relative to the $5^{\prime}$ end of Exon 1 . The ortholog promoter sequences of 11 mammalian species (including human) were extracted using TOUCAN 2 [41] The ortholog species included were: human, cow, dog, hedgehog, elephant, opossum, monkey, mouse, rabbit, chimp and rat. 
Sarhan et al. Cell signalling and Trafficking 2013,

Protein extraction, SDS-PAGE, and immunoblotting Methods for total lysate total protein extraction from Ishikawa cells, and MFGE8 immuno blotting are presented in Supplemental Materials. For the secreted MFGE8 protein quantification, the $8 \mathrm{ml}$ of media previously collected was initially subjected to ultracentrifugation at $100,000 \times \mathrm{g}$ (50TI rotor, Beckman Coulter, Brea, CA) for 2 hours followed by PBS wash and repeat ultracentrifugation for another 2 hours following a similar protocol to other previously published studies [42-43]. The entire pellet was sonicated and then loaded onto the gel followed by the protocol mentioned above. Total protein quantification of the $75 \mathrm{ml}$ flasks was performed to ensure similar cell numbers between the control and treatment samples for normalization. A sample from cell lysates was run simultaneously as a positive control.

\section{In-gel digestion and MS}

Immunoblot analysis of secreted MFGE8 protein in the culture media demonstrated, in addition to the expected $46 \mathrm{kD}$ band, a smaller sized band detected at $\sim 30 \mathrm{kD}$. The bands were absent in negative control experiments that were run simultaneously to confirm the specificity of the antibody. While the $46 \mathrm{kD}$ band was seen in the cells and in the medium, the lower molecular mass band was detected exclusively in the media and not in the cell lysate. To confirm that the $\sim 30 \mathrm{kD}$ band was, indeed, MFGE8, in addition to the immunoblotting, tandem MS analyses was performed after in-gel digestion with trypsin to generate peptides.

Briefly, pellets from two samples were loaded and separated on the same gel by SDS-PAGE as described above. One part of the gel was stained overnight with colloidal Coomassie to visualize the separated protein bands. The other part of the gel was electrotransferred onto a PVDF membrane and stained with Ponceau A to visualize the transferred proteins. Images of the separated proteins in the gel and membrane were taken and upon overlaying the images were identical. The PVDF membrane was processed for immunoblot detection of MFGE8. The immunoblot and Ponceau S images were used to precisely determine the corresponding band on the Coomassie stained gel for in-gel digestion and processing. The band was excised, destained, and the protein reduced with $10 \mathrm{mM}$ dithiothreitol (DTT) in $50 \mathrm{mM} \mathrm{NH}_{4} \mathrm{HCO}_{3}$ before alkylation with $55 \mathrm{mM}$ iodoacetamide in $50 \mathrm{mM} \mathrm{NH}_{4} \mathrm{HCO}_{3}$. Digestion with sequence grade trypsin was done overnight at a concentration of $20 \mathrm{ng} / \mu \mathrm{l}$. The generated peptides were extracted with $50 \%$ acetonitrile/ $0.1 \%$ formic acid, and dried before reconstituting in $0.1 \%$ formic acid. The peptides were separated on a C18 column and subjected to liquid chromatography MS (LC-ESI-MS/MS) on a LTQ linear ion trap mass spectrometer (Thermo Fisher Scientific, Waltham, MA).

\section{Atomic force microscopy (AFM)}

To determine whether microvesicles were produced by Ishikawa cells, pellets formed after ultracentrifugation of the
Ishikawa cell culture media were subjected to AFM. Images are generated using a force sensitive, scanning probe that flexes due to the interatomic forces it encounters at the surface of the sample. This point-by-point deflection is converted into high-resolution topographs of the surface. An aliquot of the pellet resuspension (in PBS) was added to uncoated muscovite mica (Electron Microscopy Sciences, Hatfield, PA) and allowed to air dry to encourage firm attachment to the substrate. Samples were subsequently rinsed with water to eliminate any crystals that might have formed from the buffer salts on the mica surface during drying. AFM images were collected with an Agilent 5500 scanning probe microscope (Agilent Technology, Chandler, AZ). Silicon nitride cantilevers (0.01-0.1 $\mathrm{N} / \mathrm{m}$ ) were used to scan the sample in contact mode at a rate of 0.5-2.0 lines per second at 512 points per line resolution. Images were processed as first-order flattened.

\section{Statistical analysis}

Gene expression levels (relative expression of MFGE8 to b-actin) with different doses of $E_{2}$ and $P 4$ treatments were compared using the Kruskal-Wallis test. The Holm-Sidak and Dunnet post hoc tests for pair-wise multiple comparisons were used as appropriate. Protein expression of MFGE8 with different treatments was analyzed using paired t-test. Significance was defined as $\mathrm{P}<0.05$. Results are presented as mean \pm standard error.

\section{Results}

Presence of epithelial cells markers in Ishikawa cells by immunocytochemistry

Immunocytochemical studies (Figures $1 \mathrm{~A}-1 \mathrm{H}$ ) confirmed the purity and epithelial phenotypic characteristics of the Ishikawa cells with positive staining for cytokeratin and negative staining for vimentin. Positive staining was also noted for $\mathrm{ERa}$, $E R \beta, P R$, and MFGE8, confirming the suitability of this cell line as an in vitro model for testing MFGE8 hormonal regulation in endometrial epithelial cells. Furthermore, the presence of MFGE8 receptor (av $\beta 3$ integrin), and of $\mathrm{hCG}-\mathrm{R}$, were demonstrated in the Ishikawa cells by immunofluorescence (nuclei counterstained with DAPI).

\section{Estradiol, but not progesterone or hCG, increases MFGE8} mRNA expression in Ishikawa cells

Quantitative changes in MFGE8 mRNA expression, as well as IL-6 and MUC1 (genes known to be estrogen-responsive in endometrial epithelial cells) were examined. The relative gene expression of MFGE8 $(n=6)$ was significantly increased by $E_{2}$ after 24 hours $(P<0.05)$. On the other hand, $P 4$ appeared to inhibit the estrogen stimulation but did not have a direct effect (Figure 2A). For IL-6: $E_{2}$ alone and $E_{2}$ plus P4 significantly increased IL-6 gene expression compared to controls $(P<0.05)$ (Figure 2B). For MUC1: $\mathrm{E}_{2}$ significantly increased gene expression ( ${ }^{*} P$ $<0.05$ ), but no effect was seen after $E_{2}$ plus $P 4$ treatment, or with P4 alone (Figure 2C). The treatment with hCG at $500 \mathrm{mIU} /$ 


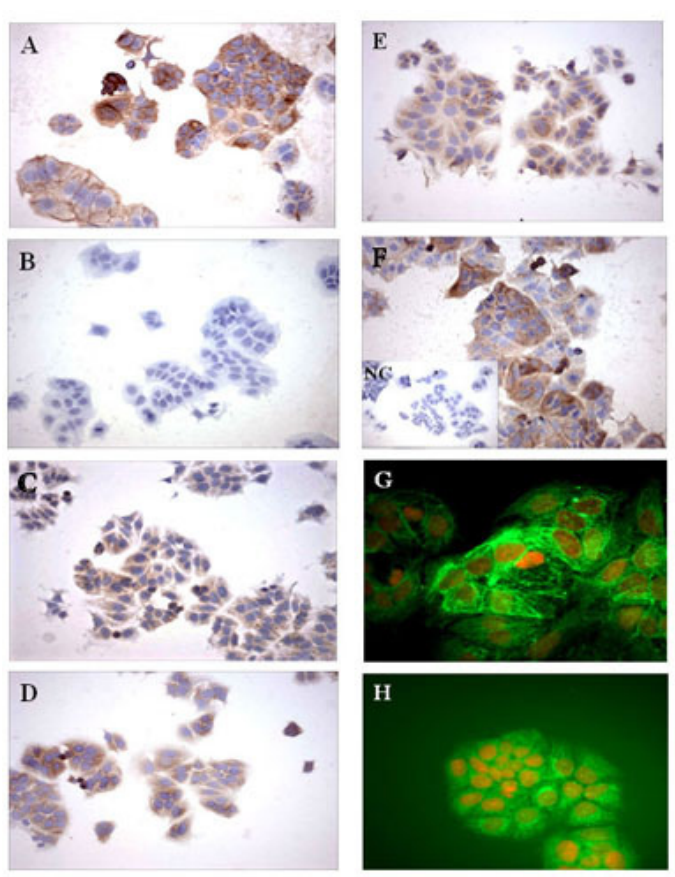

Figure 1. Immunocytochemistry results of untreated Ishikawa cells (magnification x200): (A) Cytokeratin at 1:30 dilution, marker of epithelial cells. (B) Vimentin at 1:50, marker of stromal cells. (C) ERa at 1:25. (D) ER $\beta$ at 1:25. (E) PR at 1:25. (F) MFGE8 at 1:1000, note intense staining using low dilution. Insert: $\mathrm{NC}$ : negative control using a non-immune IgG control antibody. Immunofluorescence results of untreated Ishikawa cells: (G) $\boldsymbol{\alpha} \boldsymbol{v} \boldsymbol{\beta} 3$ integrin at 1:50. (H) hCG-R (1:100). Note predominant cell membrane location for these proteins, with a filamentous distribution for $\boldsymbol{\alpha} v \boldsymbol{\beta} 3$ integrin, and a more diffuse punctuate form for hCG-R (x630 for both).

$\mathrm{ml}$ did not affect MFGE8 mRNA expression levels by 24 or 72 hours (Figure 2D).

\section{Prediction of EREs and PREs in the MFGE8 gene}

We looked for EREs of 17 bases length [42] (2 flanking $n t-1^{\text {st }}$ half site-3nt spacer- $2^{\text {nd }}$ half site-2 flanking nt) on 11 ortholog promoters of MFGE8 gene. Table 1A shows the summary of ERE predictions in these promoters at the tool sensitivity of $87 \%$.

DEREF predicted EREs on promoters of 8 orthologous species. Human and Chimp promoters have conserved $16 \mathrm{bp}$ ERE sequences (shown in red) with only most 3' nucleotide mismatched. Human and Mouse have 15 bp ERE conserved sequences (shown as bold black) with one mismatch in the second half-site and one mismatch in the second flanking nucleotide on the $5^{\prime}$ end respectively. Mouse and Rat promoters contain fully conserved 17 bp ERE (shown in blue).

PREs of length 15 bases were searched on 11 ortholog promoters of MFGE8 gene. At DPREL's default threshold we
Table 1A. Predicted EREs for MFGE8 gene.

\begin{tabular}{cccc}
\hline Species & start & strand & Pattern \\
\hline Human & 2372 & - & TT-GGTCA-GGC-TGGTC-TC \\
& 1149 & - & TT-GGCCA-GGC-TGGTC-TT \\
Dog & 1575 & + & GG-GGTGA-CAC-TGTCC-CA \\
Hedgehog & 1023 & - & AA-GGACT-AGC-TAACC-AC \\
Elephant & 248 & + & GA-GGGCT-GTG-TGGCC-GA \\
Monkey & 2675 & + & CT-AATCA-CTG-TGATC-CA \\
& 136 & - & TG-GGTCT-GCC-TGCCC-GC \\
Mouse & 3031 & - & TA-GGCCA-GGC-TGGCC-TT \\
& 81 & - & TG-AGTCC-CTC-TGGCC-TC \\
Chimp & 2421 & - & TT-GGTCA-GGC-TGGTC-TT \\
Rat & 86 & - & TG-AGTCC-CTC-TGGCC-TC \\
\hline
\end{tabular}

Human and Chimp promoters have conserved sequences of EREs (shown in red). Human and Mouse have conserved sequences of EREs (shown as bold black). Mouse and Rat promoters contain fully conserved ERE (shown in blue).

Table 1B. Predicted PREs for MFGE8 gene.

\begin{tabular}{ccccc}
\hline Species & Start & Score & Strand & Pattern \\
\hline Human & 2830 & 0.701900 & + & AGGACA-TGG-TGTTCT \\
Dog & 240 & 0.702296 & + & GGGAAA-TAA-TGTTCT \\
Chimp & 2724 & 0.701900 & + & AGGACA-TGG-TGTTCT \\
\hline
\end{tabular}

For PREs fully conserved PRE "AGGACA-TGG-TGTTCT" is present in both Human and Chimp promoters (shown in red).

were able to predict PREs on the promoters of three species (Table 1B). We observed that fully conserved PRE "AGGACATGG-TGTTCT" is present in both Human and Chimp promoters (shown in red) at the tool sensitivity of $96 \%$.

\section{hCG stimulates secretion of MFGE8 in the form of microvesicles}

Immunoblot analyses showed no significant difference in intracellular MFGE8 protein after 24, 48, and 72 hour treatment with $\mathrm{E}_{2}\left(10^{-7} \mathrm{M}\right)$ and/or $\mathrm{P}\left(10^{-6} \mathrm{M}\right)$, or with hCG $(500 \mathrm{mIU} /$ $\mathrm{ml})$. A representative blot is shown in Figure $3 \mathrm{~A}$. Detection of secreted MFGE8 was initially attempted using the $1 \mathrm{ml}$ of media per sample from the 12 well plates, but was not possible even after concentration of the media (Figure 3B). This obstacle was overcome by collecting media from more cells. Specifically, $8 \mathrm{ml}$ of media were available to assay when cells were grown in $75 \mathrm{ml}$ flasks instead of 12 well plates. After ultracentrifugation of the media as described above, the resultant pellet was sonicated and loaded in its entirety for SDS-PAGE and immunoblotting. Protein detection was compromised if less than the entire pellet was loaded. Ultracentrifugation protocols have been used in other studies (cited above) investigating secreted MFGE8 associated with microvesicles, and appears to be necessary for protein detection. 

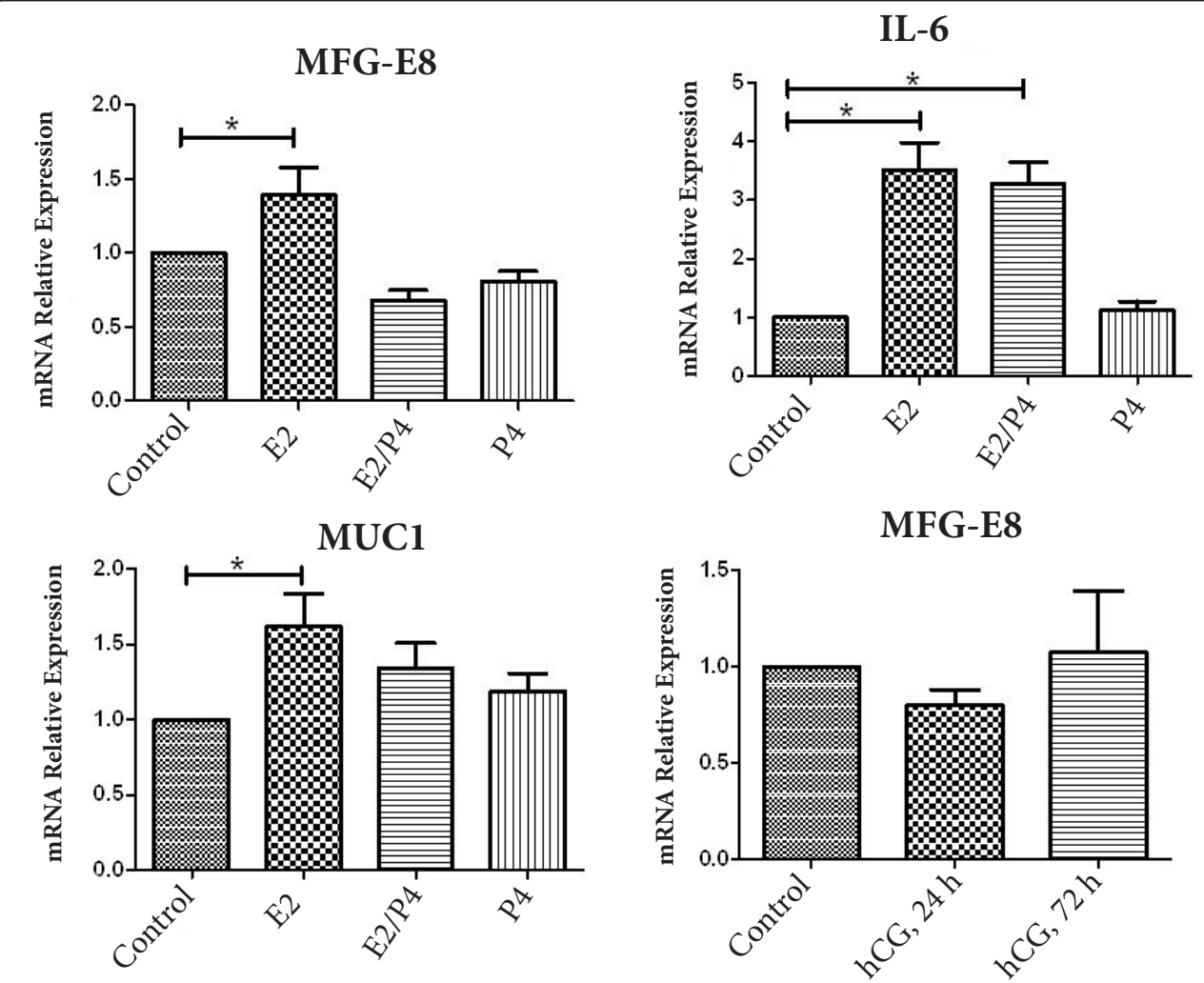

Figure 2. Quantitative changes in MFGE8, IL-6 and MUC1 mRNA expression in Ishikawa cells (relative expression of target transcripts in relation to the reference gene $\beta$-actin). (A) The relative gene expression of MFGE8 was significantly increased by E2 after 24 hours $\left({ }^{\star} \mathrm{P}<0.05\right)$. On the other hand, P4 inhibited the estrogen stimulation, and P4 alone did not have an effect. (B) For IL-6: E2 alone and E2 plus P4 significantly increased IL-6 gene expression compared to controls $\left({ }^{\star} \mathrm{P}<0.05\right)$, whereas $\mathrm{P} 4$ alone had no effect. (C) For MUC1: E2 significantly increased gene expression $\left({ }^{\star} \mathrm{P}<0.05\right)$, but no effect was seen after E2 plus P4 treatment, or with P4 alone. (D) After 24 or 72 hours, 500 mIU hCG did not modify MFG-E mRNA expression levels $(\mathrm{P}>0.5)$.

Using this ultracentrifugation/sonication protocol, a second MFGE8 secreted band was consistently visualized in addition to the expected $46 \mathrm{kD}$ band (Figures $3 \mathrm{C}$ and $3 \mathrm{D}$ ). This second band was more intense and with a lower molecular weight at $\sim 30 \mathrm{kD}$, suggesting that another form of MFGE8, not evident in any of the cell lysate samples, was also being secreted. Semiquantification of the original $46 \mathrm{kD}$ band showed a significant 1.8 fold increase in secreted MFGE8 after 72 hour treatment with $\mathrm{hCG}$ at $500 \mathrm{mlU} / \mathrm{ml}(\mathrm{P}=0.03)$ as seen in Figure 3E. Unlike hCG, $E_{2}\left(10^{-7} \mathrm{M}\right)$ and/or P4 $\left(10^{-6} \mathrm{M}\right) 72$ hour treatments did not show a significant upregulation of secreted MFGE8. In addition, the $\sim 30 \mathrm{kD}$ MFGE8 form also showed a significant increase after hCG treatment, with a 1.25 fold increase $(p<0.05)$.

\section{Characterization of secreted microvesicles by MS and AFM}

The LC-ESI-MS/MS unequivocally confirmed the identity of the second band as MFGE8 by the identification of an MFGE8 peptide with $\mathrm{m} / \mathrm{z}$ of 1765.9747 and sequence VTFLGLQH-
WVPELAR. The identification was with a significant Mascot Ion score of 55 and a significant Mascot Expect score of .0013. The sequence corresponds to the amino acids $93-107$ of the protein. The MS/MS spectra for the peptide is rich in both $b$ and $y$ ion series with very high intensities that validate the identification (Figure 4A). The ions score for the MS/MS match is based on the calculated probability, P, that the observed match between the experimental data and the database sequence is a random event, scores greater than 46 being statistically significant identifications. The expect score indicates the probability that the observed match experimental data and the database peptide sequence is random. For confident matches the significance threshold for the Expect values is $<0.1$.

The in-gel digestion and MS experiments revealed that in addition to MFGE8, several other proteins were identified in the culture medium, with molecular weights in the vicinity of the $\sim 30 \mathrm{kD}$ target, including proteins previously described in human plasma microvesicles [44]. Among those proteins were 


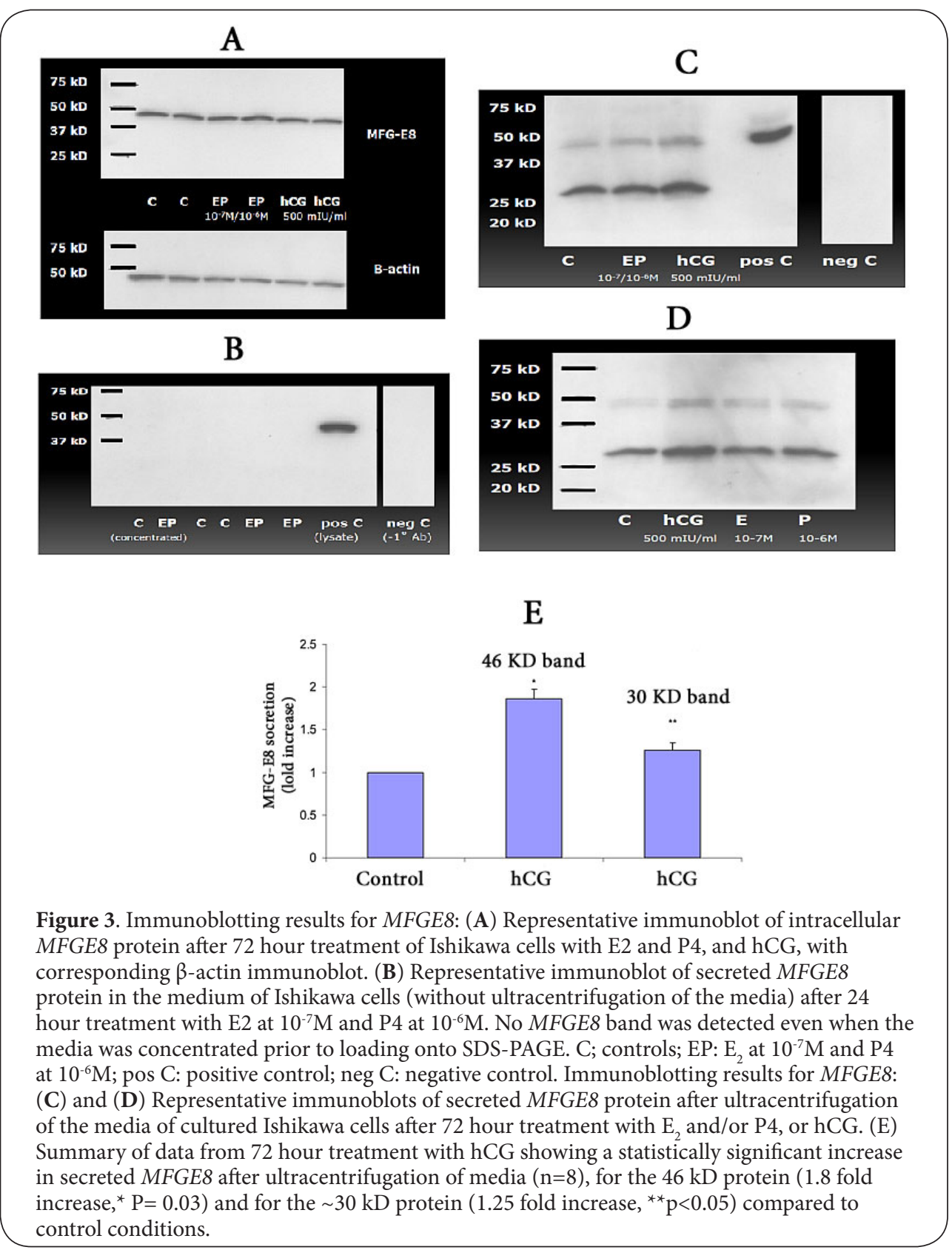

(protein score and mass-kD): annexin $(182,38690)$, actin (708, 41710-41766), glyceraldehide 3-phosphate dehydrogenase (47, $36030)$, heat shock cognate $(88,70854)$, proteasome subunit alpha $(52,29537)$, and tubulin alpha $(110,49863-50120)$.

AFM imaging confirmed the presence of secreted membranous structures, likely microvesicles from the pellets after ultracentrifugation of the Ishikawa cells media. Images from the original undiluted sample showed such an abundance of microvesicles that it made the measurement of individual dimensions difficult. However, after 1:100 dilution of the original sample, clearer images were obtained of individual microvesicles which ranged in size from 100 to $200 \mathrm{~nm}$ (Figures 4B and 4C).

\section{Discussion}

Dysregulation of MFGE8 has been linked to autoimmune and inflammatory diseases such as systemic lupus erythematosus, and severe pregnancy complications [45-47]. Given its myriad of functions, it is not surprising that MFGE8 has now been linked to such a dynamic organ as the endometrium [15,31-32]. Here, we further investigated the regulation of endometrial epithelial MFGE8 production by ovarian sex steroids, which regulate every ovulatory cycle regardless of pregnancy, and with hCG of trophoblastic origin, which is only present in a pregnant cycle. We used an established human uterine-derived epithelial cell line (Ishikawa), which shares many phenotypic 


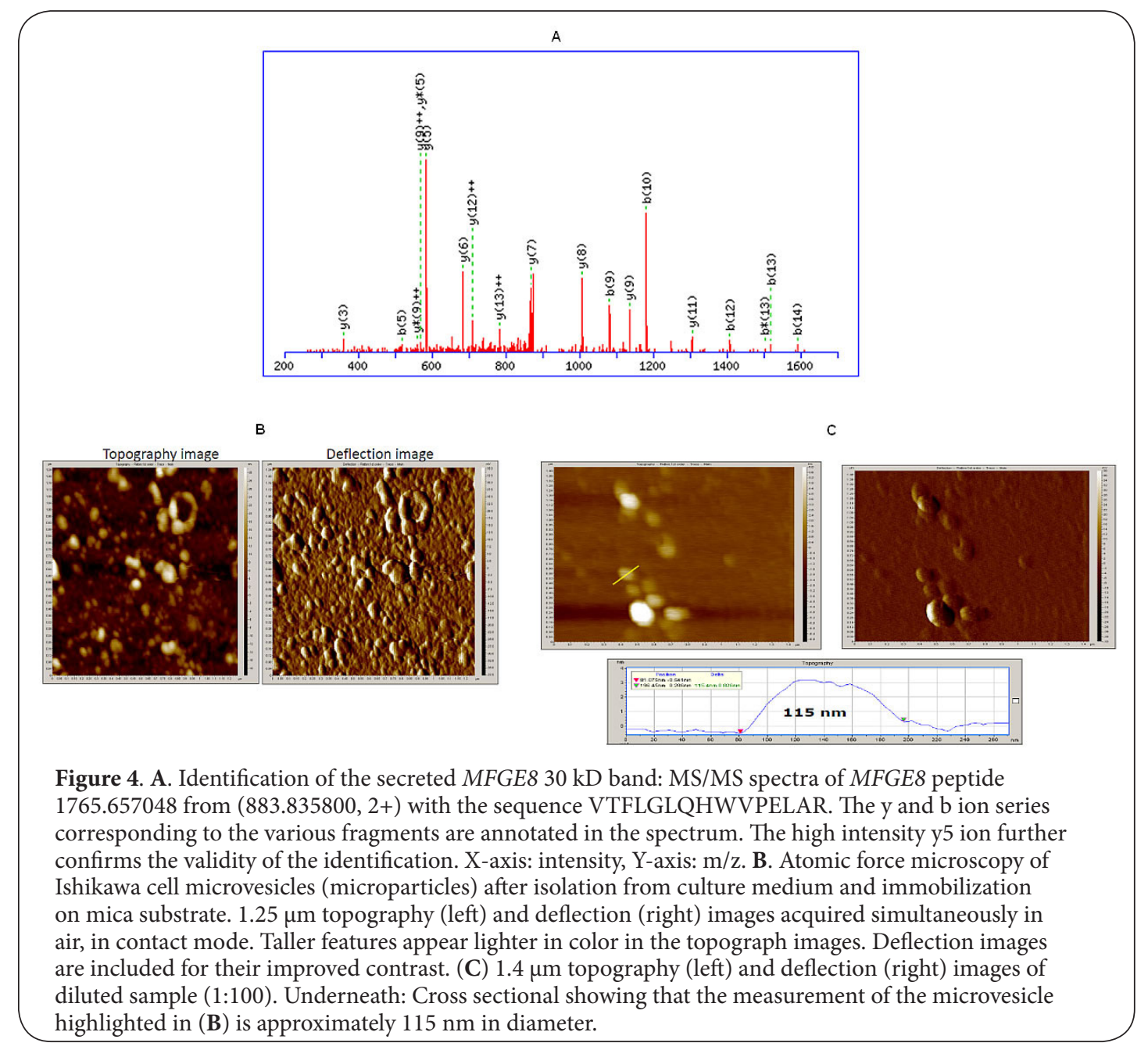

features with normal human endometrial epithelial cells $[33-36,48]$. Ishikawa cells have been shown to represent an excellent in vitro model to study the regulation of hormonally mediated events surrounding implantation [49-50].

Estradiol significantly up regulated MFGE8 expression at the transcriptional level, and P4 blunted the estrogen effect. However, neither $\mathrm{E}_{2}$ nor P4 appeared to modulate MFGE8 intracellular production or secretion. The identification of the palindromic sequence that defines EREs and PREs allows for the in silico discovery of putative hormone receptor targets in the genome. We demonstrated the presence of putative EREs and PREs in the promoters of several mammalian species suggesting a potential for control of MFGE8 by these hormones $[36,40]$. While on its own, the presence of hormone response elements in the promoter region of a gene is not evidence of the hormonal control of expression of that gene, their presence suggests that such sites could be used by activated hormone receptors and consequently could affect gene expression. The good conservation of these motifs between Human and Chimp, associated with the positional conservation of these motifs (less than 100 nt) and strand preservation, suggest conservation in closely related species.

hCG was shown having direct paracrine effects on the endometrium that precede its endocrine role of rescuing the corpus luteum, and regulates IGFBP-1 and prolactin in decidualized human endometrial stromal cells [51-54]. Here, hCG did not affect MFGE8 gene expression levels, consistent with previous results from our laboratory showing no change in primary human endometrial epithelial cells [31]. Contrarily, hCG significantly stimulated MFGE8 secretion. Our data thus far demonstrate hCG regulation of MFGE8 secretion at the protein level and not at the transcriptional level, and support the concept that MFGE8 secretion is mainly associated with microvesicles. The fact that hCG enhanced MFGE8 protein secretion but not mRNA expression has at least two possible explanations: (i) it could be a simple reflection of the shorter incubation times used for the RNA extraction studies [34]; (ii) on the other hand, the discrepancy between protein and mRNA expression suggests various levels of regulation dur- 
Sarhan et al. Cell signalling and Trafficking 2013,

http://www.hoajonline.com/journals/pdf/2054-1481-1-1.pdf

doi: 10.7243/2054-1481-1-1

ing protein synthesis, e.g., posttranscriptional, translational or posttranslational regulation [55].

Following the realization that microvesicles (microparticles) and exosomes are bioactive structures, scientific interest in their origin and roles in diseases has increased tremendously $[44,56]$. AFM imaging in this study confirmed the presence of secreted microvesicles from the Ishikawa cells, which has not been previously reported in the literature. Immunoblotting of the lysed microvesicles confirmed the association of MFGE-8 with microvesicles and explained why concentrated media did not show any detectable MFGE-8. Measurements of individual microvesicles from multiple samples showed a range of 100 to $200 \mathrm{~nm}$, which is consistent with other studies in mouse mammary epithelial cells and adipocytes [44,46,57-58].

Another interesting finding was the identification of a second secreted form of MFGE8 ( 30 kD), in addition to the expected $46 \mathrm{kD}$ form. Mass spectrometry data confirmed the presence of a peptide matching MFGE8 in that band along with other proteins typically found in plasma microvesicles at that molecular weight [44]. In contrast, the cell lysates consistently showed the expected single distinct $46 \mathrm{kD}$ MFGE8 band. This finding suggests a post-translational secretory modification to MFGE8 as opposed to the presence of two distinct mRNA transcripts, which should result in the visualization of two protein products or isoforms. It is unlikely that the second band is an artifact of proteolytic cleavage during isolation since it was consistently present along with the $46 \mathrm{kD}$ band. Furthermore, it was located at the same molecular size in all independently isolated samples, and mild conditions were used in the protein isolation process.

A similar $30 \mathrm{kD}$ truncated variant of secreted MFGE8 was reported from human breast milk of healthy females [59]. That study presented the possibility that this truncated C-terminal fragment is produced from the $46 \mathrm{kD}$ membrane bound or intracellular form by enzymatic cleavage. The Uniprot Consortium (www.uniprot.org) describes three isoforms for the human MFGE8 protein produced by alternative splicing with isoform 1 representing the intact 387 amino acid protein, while isoforms 2 and 3 are missing amino acid 1-75 and 291342 , respectively. In addition, there are reports suggesting that aberrant splicing of MFGE8, which results in a truncated protein product due to a premature stop codon, and genetic polymorphisms in MFGE8, may lead to the development of lupus [60].

\section{Conclusions}

In conclusion, this study showed that estrogen regulates MFGE8 gene expression at transcriptional level, and that hCG stimulated MFGE8 protein secretion. Moreover, hCG stimulated MFGE8 secretion in association with microvesicles, pointing to an early dialogue between the trophoblast and the endometrium. To the best of our knowledge this is the first demonstration of microvesicular secretion of a regulatory protein by human endometrial epithelial cells. We acknowledge that these studies were performed in an established epithelial cell line and need to be recapitulated in primary cells. Taking together our previous data in human endometrium, primary cells and now Ishikawa cells [15,30-32], we propose a unifying hypotesis that a multifactorial MFGE8 regulation is maintained by estrogen upregulation of $\mathrm{mRNA}$, prolactin upregulation of intracellular protein production, and hCG triggers the actual secretion of MFGE8. These data support that MFGE8 is involved in the estrogen-, prolactin- and hCG-dependent regulation of endometrial-embryonic effects at the time of implantation, and also that MFGE8 could be a key modulator of endometrial physiology acting as an exocrine, paracrine and/or autocrine factor, with microvesicular participation in cellular trafficking information in the non-pregnant and pregnant endometrium.

\section{Competing interest}

The authors declare that they have no competing interests.

Authors' contributions

\begin{tabular}{|l|c|c|c|c|c|c|c|c|c|c|c|}
\hline $\begin{array}{l}\text { Authors' } \\
\text { contributions }\end{array}$ & AS & SB & LY & SA & TJ & TB & JON & CS & MK & VBB & SO \\
\hline $\begin{array}{l}\text { Research concept and } \\
\text { design }\end{array}$ & $\checkmark$ & $\checkmark$ & - & -- & $\checkmark$ & $\checkmark$ & $\checkmark$ & -- & - & - & $\checkmark$ \\
\hline $\begin{array}{l}\text { Collection and/or } \\
\text { assembly of data }\end{array}$ & $\checkmark$ & -- & $\checkmark$ & $\checkmark$ & -- & -- & -- & $\checkmark$ & - & -- & - \\
\hline $\begin{array}{l}\text { Data analysis and } \\
\text { interpretation }\end{array}$ & $\checkmark$ & $\checkmark$ & -- & -- & -- & -- & - & -- & $\checkmark$ & $\checkmark$ & - \\
\hline Writing the article & $\checkmark$ & -- & -- & -- & -- & -- & - & -- & -- & - & $\checkmark$ \\
\hline $\begin{array}{l}\text { Critical revision of the } \\
\text { article }\end{array}$ & -- & $\checkmark$ & -- & -- & -- & -- & -- & -- & -- & -- & -- \\
\hline $\begin{array}{l}\text { Final approval of } \\
\text { article }\end{array}$ & -- & $\checkmark$ & -- & -- & -- & -- & -- & -- & -- & -- & $\checkmark$ \\
\hline Statistical analysis & $\checkmark$ & $\checkmark$ & -- & -- & -- & -- & -- & -- & -- & -- & -- \\
\hline
\end{tabular}

Acknowledgement and funding

We thank Ms. Natalie Lonergan from the Department of Surgery for assistance with atomic force microscopy experiments. This work was supported by a research grant from The Jones Institute Foundation and Eastern Virginia Medical School to SO and SB.

\section{Publication history}

Editor: Edgar Serfling, University of Würzburg, Germany. EICs: Matthias Gaestel, Hannover Medical University, Germany. Ulhas P. Naik, University of Delaware, USA.

Received: 20-Sep-2013 Revised: 27-Sep-2013

Re-Revised: 30-Sep-2013 Accepted: 01-Oct-2013

Published: 17-Oct-2013

\section{References}

1. Dey SK, Lim H, Das SK, Reese J, Paria BC, Daikoku T and Wang H. Molecular cues to implantation. Endocr Rev. 2004; 25:341-73. | Article I PubMed

2. Maruyama T and Yoshimura Y. Molecular and cellular mechanisms for differentiation and regeneration of the uterine endometrium. Endocr J. 2008; 55:795-810. I Article I PubMed

3. Yoshinaga K. Research on Blastocyst Implantation Essential Factors (BIEFs). Am J Reprod Immunol. 2010; 63:413-24. I Article I PubMed

4. Singh $M$, Chaudhry $P$ and Asselin $E$. Bridging endometrial receptivity and implantation: network of hormones, cytokines, and growth factors. J Endocrinol. 2011; 210:5-14. | Article | PubMed

5. Haouzi D, Dechaud H, Assou S, De Vos J and Hamamah S. Insights into 
Sarhan et al. Cell signalling and Trafficking 2013,

human endometrial receptivity from transcriptomic and proteomic data. Reprod Biomed Online. 2012; 24:23-34. | Article | PubMed

6. Telgmann $\mathrm{R}$ and Gellersen B. Marker genes of decidualization: activation of the decidual prolactin gene. Hum Reprod Update. 1998; 4:472-9. | Article I PubMed

7. Dunn CL, Kelly RW and Critchley HO. Decidualization of the human endometrial stromal cell: an enigmatic transformation. Reprod Biomed Online. 2003; 7:151-61. | Article | PubMed

8. Gellersen B and Brosens J. Cyclic AMP and progesterone receptor crosstalk in human endometrium: a decidualizing affair. J Endocrinol. 2003; 178:357-72. | Article | PubMed

9. Jabbour HN, Kelly RW, Fraser HM and Critchley HO. Endocrine regulation of menstruation. Endocr Rev. 2006; 27:17-46. | Article | PubMed

10. Gellersen B, Brosens IA and Brosens JJ. Decidualization of the human endometrium: mechanisms, functions, and clinical perspectives. Semin Reprod Med. 2007; 25:445-53. | Article | PubMed

11. Horcajadas JA, Riesewijk A, Dominguez F, Cervero A, Pellicer A and Simon C. Determinants of endometrial receptivity. Ann N Y Acad Sci. 2004; 1034:166-75. | Article | PubMed

12. Giudice LC. Application of functional genomics to primate endometrium: insights into biological processes. Reprod Biol Endocrinol. 2006; 4 Suppl 1:S4. | Article | PubMed Abstract | PubMed Full Text

13. Aghajanova L, Hamilton AE and Giudice LC. Uterine receptivity to human embryonic implantation: histology, biomarkers, and transcriptomics. Semin Cell Dev Biol. 2008; 19:204-11. | Article | PubMed Abstract | PubMed Full Text

14. Mirkin S, Arslan M, Churikov D, Corica A, Diaz JI, Williams S, Bocca S and Oehninger $S$. In search of candidate genes critically expressed in the human endometrium during the window of implantation. Hum Reprod. 2005; 20:2104-17. | Article | PubMed

15. Franchi A, Bocca S, Anderson S, Riggs R and Oehninger S. Expression of milk fat globule EGF-factor 8 (MFG-E8) mRNA and protein in the human endometrium and its regulation by prolactin. Mol Hum Reprod. 2011; 17:360-71. | Article | PubMed

16. Peterson JA, Zava DT, Duwe AK, Blank EW, Battifora $\mathrm{H}$ and Ceriani RL. Biochemical and histological characterization of antigens preferentially expressed on the surface and cytoplasm of breast carcinoma cells identified by monoclonal antibodies against the human milk fat globule. Hybridoma. 1990; 9:221-35. | Article | PubMed

17. Taylor MR, Couto JR, Scallan CD, Ceriani RL and Peterson JA. Lactadherin (formerly BA46), a membrane-associated glycoprotein expressed in human milk and breast carcinomas, promotes Arg-Gly-Asp (RGD)dependent cell adhesion. DNA Cell Biol. 1997; 16:861-9. | Article | PubMed

18. Ensslin MA and Shur BD. The EGF repeat and discoidin domain protein, SED1/MFG-E8, is required for mammary gland branching morphogenesis. Proc Natl Acad Sci U S A. 2007; 104:2715-20. | Article | PubMed Abstract | PubMed Full Text

19. Raymond A, Ensslin MA and Shur BD. SED1/MFG-E8: a bi-motif protein that orchestrates diverse cellular interactions. J Cell Biochem. 2009; 106:957-66. | Article | PubMed Abstract | PubMed Full Text

20. Hanayama R, Tanaka M, Miwa K, Shinohara A, Iwamatsu A and Nagata S. Identification of a factor that links apoptotic cells to phagocytes. Nature. 2002; 417:182-7. | Article | PubMed

21. Nandrot EF, Anand M, Almeida D, Atabai K, Sheppard D and Finnemann SC. Essential role for MFG-E8 as ligand for alphavbeta5 integrin in diurnal retinal phagocytosis. Proc Natl Acad Sci U S A. 2007; 104:1200510. | Article | PubMed Abstract | PubMed Full Text

22. Fens $M H$, Mastrobattista $E$, de Graaff AM, Flesch FM, Ultee $A$, Rasmussen JT, Molema G, Storm G and Schiffelers RM. Angiogenic endothelium shows lactadherin-dependent phagocytosis of aged erythrocytes and apoptotic cells. Blood. 2008; 111:4542-50. | Article | PubMed

23. Aziz MM, Ishihara S, Rumi MA, Mishima Y, Oshima N, Kadota C, Moriyama I, Li YY, Rahman FB, Otani A, Oka A, Ishimura N, Kadowaki $Y$, Amano $Y$ and Kinoshita $Y$. Prolactin induces MFG-E8 production in macrophages via transcription factor C/EBPbeta-dependent pathway.
Apoptosis. 2008; 13:609-20. | Article | PubMed

24. Silvestre JS, Thery C, Hamard G, Boddaert J, Aguilar B, Delcayre A, Houbron C, Tamarat R, Blanc-Brude O, Heeneman S, Clergue M, Duriez M, Merval R, Levy B, Tedgui A, Amigorena S and Mallat Z. Lactadherin promotes VEGF-dependent neovascularization. Nat Med. 2005; 11:499506. | Article | PubMed

25. Ensslin MA and Shur BD. Identification of mouse sperm SED1, a bimotif EGF repeat and discoidin-domain protein involved in sperm-egg binding. Cell. 2003; 114:405-17. | Article | PubMed

26. Aoki N. Regulation and functional relevance of milk fat globules and their components in the mammary gland. Biosci Biotechnol Biochem. 2006; 70:2019-27. | Article | PubMed

27. Bu HF, Zuo XL, Wang X, Ensslin MA, Koti V, Hsueh W, Raymond AS, Shur $\mathrm{BD}$ and Tan XD. Milk fat globule-EGF factor $8 /$ lactadherin plays a crucial role in maintenance and repair of murine intestinal epithelium. $J$ Clin Invest. 2007; 117:3673-83. | Article | PubMed Abstract | PubMed Full Text

28. Raymond AS, Elder B, Ensslin M and Shur BD. Loss of SED1/MFG-E8 results in altered luminal physiology in the epididymis. Mol Reprod Dev. 2010; 77:550-63. | Article | PubMed Abstract I PubMed Full Text

29. Newburg DS, Peterson JA, Ruiz-Palacios GM, Matson DO, Morrow AL, Shults J, Guerrero ML, Chaturvedi P, Newburg SO, Scallan CD, Taylor $\mathrm{MR}$, Ceriani RL and Pickering LK. Role of human-milk lactadherin in protection against symptomatic rotavirus infection. Lancet. 1998; 351:1160-4. | Article | PubMed

30. Bocca SM, Anderson S, Amaker B, Swanson RJ, Franchi A, Lattanzio F and Oehninger S. Milk fat globule epidermal growth factor 8 (MFG-E8): a novel protein in the mammalian endometrium with putative roles in implantation and placentation. Placenta. 2012; 33:795-802. | Article | PubMed

31. Riggs RM, Bocca S, Anderson S, Franchi A, Rhavi BS and Oehninger S. Epithelial cell protein milk fat globule-epidermal growth factor 8 and human chorionic gonadotropin regulate stromal cell apoptosis in the human endometrium. Fertil Steril. 2012; 98:1549-56 e3. | Article | PubMed

32. Bocca S, Anderson S and Oehninger S. Milk fat globule epithelial growth factor 8 (MFGE8) regulates human endometrial endothelial cell adhesion and proliferation. Fertil. Steril. 2010; 94:S215-S216. | Article

33. Nishida M. The Ishikawa cells from birth to the present. Hum Cell. 2002; 15:104-17. | Article | PubMed

34. Bocca SM and Archer DF. Raloxifene (RIX) has antiestrogenic effect on Vascular Endothelial Growth Factor (VEGF) mRNA and protein while down-regulating progesterone receptors in a human endometrial cell line in vitro. Fertil. Steril. 2005, 84:S119-120. | Article

35. Heneweer C, Schmidt M, Denker HW and Thie M. Molecular mechanisms in uterine epithelium during trophoblast binding: the role of small GTPase RhoA in human uterine Ishikawa cells. J Exp Clin Assist Reprod. 2005; 2:4. | Article | PubMed Abstract | PubMed Full Text

36. Zhang X, Bocca S, Franchi A, Anderson S, Kaur M, Bajic VB and Oehninger S. Do GnRH analogues directly affect human endometrial epithelial cell gene expression? Mol Hum Reprod. 2010; 16:347-60. | Article | PubMed

37. Sherwin JR, Sharkey AM, Cameo P, Mavrogianis PM, Catalano RD, Edassery $S$ and Fazleabas AT. Identification of novel genes regulated by chorionic gonadotropin in baboon endometrium during the window of implantation. Endocrinology. 2007; 148:618-26. | Article | PubMed

38. Krikun G, Sakkas D, Schatz F, Buchwalder L, Hylton D, Tang C and Lockwood CJ. Endometrial angiopoietin expression and modulation by thrombin and steroid hormones: a mechanism for abnormal angiogenesis following long-term progestin-only contraception. Am J Pathol. 2004; 164:2101-7. | Article | PubMed Abstract | PubMed Full Text

39. Yang $\mathrm{H}$, Lei $\mathrm{CX}$ and Zhang W. Human chorionic gonadotropin (hCG) regulation of galectin-3 expression in endometrial epithelial cells and endometrial stromal cells. Acta Histochem. 2013; 115:3-7. | Article | PubMed

40. Bajic VB, Tan SL, Chong A, Tang S, Strom A, Gustafsson JA, Lin CY and Liu ET. Dragon ERE Finder version 2: A tool for accurate detection and 
Sarhan et al. Cell signalling and Trafficking 2013,

analysis of estrogen response elements in vertebrate genomes. Nucleic Acids Res. 2003; 31:3605-7. | Article | PubMed Abstract | PubMed Full $\underline{\text { Text }}$

41. Aerts S, Van Loo P, Thijs G, Mayer H, de Martin R, Moreau Y and De Moor B. TOUCAN 2: the all-inclusive open source workbench for regulatory sequence analysis. Nucleic Acids Res. 2005; 33:W393-6. | Article | PubMed Abstract | PubMed Full Text

42. Veron P, Segura E, Sugano G, Amigorena S and Thery C. Accumulation of MFG-E8/lactadherin on exosomes from immature dendritic cells. Blood Cells Mol Dis. 2005; 35:81-8. | Article | PubMed

43. Aoki N, Jin-no S, Nakagawa Y, Asai N, Arakawa E, Tamura N, Tamura T and Matsuda T. Identification and characterization of microvesicles secreted by 3T3-L1 adipocytes: redox- and hormone-dependent induction of milk fat globule-epidermal growth factor 8-associated microvesicles. Endocrinology. 2007; 148:3850-62. | Article | PubMed

44. Jin M, Drwal G, Bourgeois T, Saltz J and Wu HM. Distinct proteome features of plasma microparticles. Proteomics. 2005; 5:1940-52. | Article I PubMed

45. Hanayama R, Tanaka M, Miyasaka K, Aozasa K, Koike M, Uchiyama Y and Nagata $S$. Autoimmune disease and impaired uptake of apoptotic cells in MFG-E8-deficient mice. Science. 2004; 304:1147-50. | Article | PubMed

46. Toth $B$, Lok CA, Boing A, Diamant $M$, van der Post JA, Friese $K$ and Nieuwland R. Microparticles and exosomes: impact on normal and complicated pregnancy. Am J Reprod Immunol. 2007; 58:389-402. | Article | PubMed

47. Yamaguchi $\mathrm{H}$, Takagi J, Miyamae T, Yokota S, Fujimoto T, Nakamura S, Ohshima S, Naka T and Nagata S. Milk fat globule EGF factor 8 in the serum of human patients of systemic lupus erythematosus. J Leukoc Biol. 2008; 83:1300-7. | Article | PubMed

48. Lessey BA, Ilesanmi AO, Castelbaum AJ, Yuan L, Somkuti SG, Chwalisz K and Satyaswaroop PG. Characterization of the functional progesterone receptor in an endometrial adenocarcinoma cell line (Ishikawa): progesterone-induced expression of the alpha1 integrin. I Steroid Biochem Mol Biol. 1996; 59:31-9. | Article | PubMed

49. Castelbaum AJ, Ying L, Somkuti SG, Sun J, llesanmi AO and Lessey BA. Characterization of integrin expression in a well differentiated endometrial adenocarcinoma cell line (Ishikawa). J Clin Endocrinol Metab. 1997; 82:136-42. | Article | PubMed

50. Hannan NJ, Paiva P, Dimitriadis E and Salamonsen LA. Models for study of human embryo implantation: choice of cell lines? Biol Reprod. 2010; 82:235-45. | Article | PubMed

51. Bonduelle ML, Dodd R, Liebaers I, Van Steirteghem A, Williamson R and Akhurst R. Chorionic gonadotrophin-beta mRNA, a trophoblast marker, is expressed in human 8-cell embryos derived from tripronucleate zygotes. Hum Reprod. 1988; 3:909-14. | PubMed

52. Licht $P$, Fluhr $H$, Neuwinger J, Wallwiener $D$ and Wildt $L$. Is human chorionic gonadotropin directly involved in the regulation of human implantation? Mol Cell Endocrinol. 2007; 269:85-92. | Article | PubMed

53. Fluhr H, Krenzer S, Deperschmidt M, Zwirner M, Wallwiener D and Licht P. Human chorionic gonadotropin inhibits insulin-like growth factorbinding protein-1 and prolactin in decidualized human endometrial stromal cells. Fertil Steril. 2006; 86:236-8. | Article | PubMed

54. Mansour R, Tawab N, Kamal O, El-Faissal Y, Serour A, Aboulghar M and Serour $\mathrm{G}$. Intrauterine injection of human chorionic gonadotropin before embryo transfer significantly improves the implantation and pregnancy rates in in vitro fertilization/intracytoplasmic sperm injection: a prospective randomized study. Fertil Steril. 2011; 96:1370$1374 \mathrm{e} 1 . \mid$ Article | PubMed

55. Tian $Q$, Stepaniants $S B$, Mao $M$, Weng L, Feetham MC, Doyle MJ, Yi EC, Dai H, Thorsson V, Eng J, Goodlett D, Berger JP, Gunter B, Linseley PS, Stoughton RB, Aebersold R, Collins SJ, Hanlon WA and Hood LE. Integrated genomic and proteomic analyses of gene expression in Mammalian cells. Mol Cell Proteomics. 2004; 3:960-9. | Article | PubMed

56. Diamant M, Tushuizen ME, Sturk A and Nieuwland R. Cellular microparticles: new players in the field of vascular disease? Eur J Clin
Invest. 2004; 34:392-401. | Article | PubMed

57. Oshima K, Aoki N, Kato T, Kitajima K and Matsuda T. Secretion of a peripheral membrane protein, MFG-E8, as a complex with membrane vesicles. Eur J Biochem. 2002; 269:1209-18. | Article | PubMed

58. Gyorgy B, Szabo TG, Pasztoi M, Pal Z, Misjak P, Aradi B, Laszlo V, Pallinger E, Pap E, Kittel A, Nagy G, Falus A and Buzas El. Membrane vesicles, current state-of-the-art: emerging role of extracellular vesicles. Cell $\mathrm{Mol}$ Life Sci. 2011; 68:2667-88. | Article | PubMed Abstract | PubMed Full $\underline{\text { Text }}$

59. Giuffrida MG, Cavaletto M, Giunta C, Conti A and Godovac-Zimmermann $J$. Isolation and characterization of full and truncated forms of human breast carcinoma protein BA46 from human milk fat globule membranes. J Protein Chem. 1998; 17:143-8. | Article | PubMed

60. Yamaguchi H, Fujimoto T, Nakamura S, Ohmura K, Mimori T, Matsuda $\mathrm{F}$ and Nagata S. Aberrant splicing of the milk fat globule-EGF factor 8 (MFG-E8) gene in human systemic lupus erythematosus. Eur J Immunol. 2010; 40:1778-85. | Article | PubMed

\section{Citation:}

Sarhan A, Bocca S, Yu L, Anderson S, Jacot T, Burch T, Nyalwidhe JO, Sullivan C, Kaur M, Bajic VB and Oehninger S. Human endometrial milk fat globule-epidermal growth factor 8 (MFGE8) is up regulated by estradiol at the transcriptional level, and its secretion via microvesicles is stimulated by human chorionic gonadotropin (hCG). Cell Signal Traffic. 2013; 1:1.

http://dx.doi.org/10.7243/2054-1481-1-1 